\title{
STUDIES ON NORMAL AND LEUKEMIC LEUKOCYTES. IV. TETRAHYDROFOLATE-DEPENDENT ENZYME SYSTEMS AND DIHYDROFOLIC REDUCTASE *
}

\author{
By J. R. BERTINO, $\dagger$ ROBERT SILBER, $\ddagger$ M. FREEMAN, A. ALENTY, M. ALBRECHT, \\ BEVERLY W. GABRIO, AND F. M. HUENNEKENS §
}

\author{
(From the Department of Biochemistry, University of Washington, and King County Central \\ Blood Bank, Seattle, Wash.)
}

(Submitted for publication May 31, 1962 ; accepted August 16, 1963)

A number of investigations (3-6) have been concerned with biochemical characteristics of normal and leukemic leukocytes with special reference to enzymatic reactions that might represent potential targets for chemotherapeutic agents. Tetrahydrofolate-dependent enzyme systems provide a particularly promising area for this approach, since they mediate reactions in which 1-carbon units are incorporated into precursors of nucleic acids and proteins, namely, inosinate, thymidylate, methionine, histidine, and serine (7-9). Further support for this reasoning is provided by other experimental facts: $a$ ) the levels of folic acid and folinic acid are considerably higher in acute leukemia cells than in normal cells $(10) ; b$ ) the folic acid antagonists (aminopterin, amethopterin, and dichloroamethopterin) frequently produce transient remissions in patients with acute leukemia; and $c$ ) the rate of incorporation of $\mathrm{C}^{14}$ formate and $\mathrm{C}^{14}$-formaldehyde into purines and into DNA-thymine is markedly increased in chronic myelocytic leukemic cells as compared with normal cells, and these processes are inhibited by aminopterin and amethopterin (11-13).

In the present investigation several tetrahydrofolate-dependent enzymes and dihydrofolic reductase (14) have been studied in circulating human leukocytes. A comparison has been made of the level of these enzymes in normal cells and in

* This work was supported by a grant (P-203) from the American Cancer Society. Preliminary reports of this work have appeared elsewhere $(1,2)$.

$\dagger$ Postdoctoral fellow of the National Heart Institute. Present address: Department of Pharmacology, Yale University School of Medicine, New Haven, Conn.

¥ Special fellow of the National Cancer Institute. Present address: Department of Medicine, New York University School of Medicine, New York, N. Y.

$\S$ Present address: Division of Biochemistry, Scripps Clinic and Research Foundation, La Jolla, Calif. the cells of chronic myelocytic, chronic lymphocytic, and acute leukemias. Similar studies have been reported recently by Wilmanns $(15,16)$. The increase in the level of leukocyte dihydrofolic reductase in patients treated with amethopterin has been described elsewhere $(17,18)$.

\section{METHODS}

The following materials ${ }^{1}$ were used: ATP; ${ }^{2}$ DPN, TPN, glucose-6-phosphate, Tris, pyruvate, and protamine sulfate ${ }^{3}$ pyridoxal phosphate; ${ }^{4}$ dextran (average mol wt $=180,000) ;{ }^{5}$ EDTA ; ${ }^{6}$ crystalline bovine serum albumin ; ${ }^{7}$ sodium heparin ; ${ }^{8}$ monomethylol dimethylhydantoin ; 9 DEAE cellulose (capacity, 0.6 to $0.8 \mathrm{mEq}$ per g); 10 folic acid; ${ }^{11}$ dihydrofolate and tetrahydrofolate prepared by previously published methods $(19,20) ; 12$ $N^{5}$-formyl tetrahydrofolate (folinic acid);13 $N^{5}, N^{10}$ methenyl tetrahydrofolate (21) and $N^{10}$-formyl tetrahydrofolate (22) prepared from folinic acid by the indicated methods; formate-activating enzyme isolated from

1 Abbreviations: ADP, ATP, adenosine di- and triphosphate; DPN, TPN, di- and triphosphopyridine nucleotide; DPNH, TPNH, reduced DPN and TPN; $P_{1}$, inorganic phosphate; EDTA, disodium ethylenediaminetetraacetate; DEAE, diethylaminoethyl; Tris, tris(hydroxymethyl)aminomethane; CLL, chronic lymphocytic leukemia; CML, chronic myelocytic leukemia; ALL, acute lymphoblastic leukemia (child); and AL, acute leukemia.

2 Pabst Laboratories, Milwaukee, Wis.

3 Sigma Chemical Co., St. Louis, Mo.

4 California Corporation for Biochemical Research, Los Angeles, Calif.

5 Pharmachem Corp., Bethlehem, Pa.

${ }^{6}$ J. T. Baker Chemical Co., Phillipsburg, N. J.

7 Armour Pharmaceutical Co., Kankakee, III.

8 Invenex Co., San Francisco, Calif.

9 E. I. DuPont de Nemours and Co., Wilmington, Del.

10 Eastman Kodak Co., Rochester, N. Y.

11 Nutritional Biochemicals Corp., Cleveland, Ohio.

12 Dr. J. G. Ozols kindly supplied samples of tetrahydrofolate.

13 Gift of Dr. E. L. R. Stokstad, Lederle Laboratories, Pearl River, N. Y. 
Micrococcus aerogenes (23) ${ }^{14}$ or from chicken liver (24) ; crystalline samples of busulfan, 6-mercaptopurine, and chlorambucil; 15 nitrogen mustard; 16 and amethopterin, dichloramethopterin, and aminopterin. ${ }^{17}$

Blood smears were stained with Wright's stain, and leukocyte counts were performed in duplicate. Hemoglobin was measured by its absorbancy at $410 \mathrm{~m} \mu$ (millimolar extinction coefficient $=120)$. Protein was determined by the biuret method (25) with crystalline bovine serum albumin as the standard. Assay systems involving changes in absorbancy were performed in the Beckman spectrophotometer, model DU, with cuvettes of $1-\mathrm{cm}$ optical path.

\section{Enzyme assays}

The various tetrahydrofolate-dependent enzymes (formate-activating enzyme $(26), N^{5}, N^{10}$-methylene tetrahydrofolic dehydrogenase (27), serine hydroxymethylase (28), cyclohydrolase (29), and $N^{10}$-formyl tetrahydrofolate deacylase (29) were assayed in leukocyte lysates by the methods indicated in the above references. Detailed descriptions of these enzyme assays have been presented elsewhere $(30,31)$. Serine hydroxymethylase was measured in most instances by coupling the hydroxymethylase reaction with $N^{5}, N^{10}$-methylene tetrahydrofolic dehydrogenase. This coupled assay for the hydroxymethylase, which requires that the dehydrogenase be present in excess, was valid for all leukocyte preparations except those of chronic lymphocytic leukemia. In the latter instance, serine hydroxymethylase was determined by an alternate method (32) based upon the tetrahydrofolate- and glycine-dependent disappearance of HCHO. Dihydrofolic reductase was measured by either the "direct" or "indirect" methods (14). Assays for glucose-6-phosphate dehydrogenase (33) and lactic dehydrogenase (34) were performed by the indicated procedures.

The "levels" of the various enzymes are expressed in terms of their activities, i.e., micromoles of product formed per hour per milligram of protein in the lysate. Assays were performed in duplicate at $37^{\circ} \mathrm{C}$, and two or more different amounts ( 0.1 to $5.0 \mathrm{mg}$ of protein) of lysate were used.

\section{Clinical material}

"Normal" leukocytes were isolated from the blood of healthy donors at the King County Central Blood Bank. Patients with leukemia were studied before therapy or were in relapse and not currently on any chemotherapeutic regimen. The leukocyte count of all patients with chronic lymphocytic leukemia exceeded 50,000 per $\mathrm{ml}$ with more than $85 \%$ small lymphocytes. Only those chronic myelocytic leukemia patients with leukocyte counts above 40,000 per $\mathrm{ml}$ and with more than $30 \% \mathrm{im}$ -

14 Kindly supplied by Dr. H. R. Whiteley.

15 Kindly supplied by Dr. S. Searle, Burroughs Wellcome and Co., Tuckahoe, N. Y.

$16 \mathrm{Gift}$ of Dr. D. M. Donohue.

${ }^{17}$ Kindly supplied by J. M. Ruegsegger, Lederle Laboratories, Pearl River, N. Y. mature granulocytic forms were studied. In patients with acute leukemia, the leukocyte count exceeded 25,000 per $\mathrm{ml}$, with at least $75 \%$ blast forms.

\section{Isolation of leukocytes}

Human blood was collected in one of the following media: heparin, $2 \mathrm{mg}$ per $100 \mathrm{ml}$ of blood; acid-citratedextrose (National Institutes of Health, formula A), 15 $\mathrm{ml}$ per $100 \mathrm{ml}$ of blood; or EDTA $(0.75 \mathrm{~g}$ EDTA and $0.35 \mathrm{~g} \mathrm{NaCl}$ in $50 \mathrm{ml}$ of water), $10 \mathrm{ml}$ per $100 \mathrm{ml}$ of blood. The blood was processed within 30 minutes after collection, and all operations were performed at $4^{\circ} \mathrm{C}$. Centrifugations were carried out in the International refrigerated centrifuge, model PR- 2 .

One vol of blood was added to 2 vol of $3 \%$ dextran in $0.15 \mathrm{M} \mathrm{NaCl}$ contained in a glass cylinder. The mixture was inverted carefully several times, and sedimentation under gravity was allowed to proceed for $30 \mathrm{~min}$ utes or until a distinct separation of the red cell layer had occurred. The supernatant fluid, containing most of the leukocytes, was removed and centrifuged for $4 \mathrm{~min}-$ utes at $180 \times g$. The supernatant fraction, containing most of the platelets, was discarded. Residual dextran was removed by mixing the leukocyte mass with 5 vol of $0.15 \mathrm{M} \mathrm{NaCl}$, centrifuging for 4 minutes at $500 \times g$, and discarding the supernatant fluid.

Selective lysis of the remaining erythrocytes was performed by the addition of 3 vol of cold distilled water to the above leukocyte pellet. The cells were stirred vigorously for exactly 30 seconds, and the suspension was readjusted to isotonicity by the addition of 1 vol of 0.6 $\mathrm{M} \mathrm{KCl}$. After centrifugation for 4 minutes at $500 \times g$, the hemoglobin-containing supernatant fluid was discarded. Removal of the thin layer of red material (erythrocyte residues and platelets) above the leukocytes was accomplished by the careful addition of $1.0 \mathrm{ml}$ of $0.15 \mathrm{M} \mathrm{NaCl}$ to the top of the pellet and gentle swirling of the fluid, with precautions to keep the bulk of the leukocyte pellet undisturbed. After removal of the supernatant fluid by aspiration, the remaining leukocytes were suspended in $10 \mathrm{vol}$ of $0.15 \mathrm{M} \mathrm{NaCl}$ and centrifuged for 4 minutes at $500 \times g$. The supernatant fraction was discarded, and any red material still remaining at the top of the leukocyte pellet was removed again as described above. Finally, the leukocytes were suspended in 4 vol of $0.08 \mathrm{M}$ potassium phosphate buffer, $\mathrm{pH} 7.5$.

\section{Preparation of leukocyte lysates}

Homogenization. A 1:4 suspension of leukocytes was placed in a Virtis flask surrounded by an ice bath and homogenized for 3 minutes at maximal speed $(45,000 \mathrm{rpm})$ in a Virtis " 45 " homogenizer. After centrifugation for 15 minutes at $10,000 \times g$ (high speed attachment, International refrigerated centrifuge, model PR-2), the supernatant fluid was collected, and the residue was washed

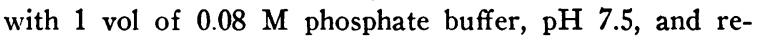
centrifuged; the two supernatant fractions were pooled and used as the leukocyte lysate.

Freezing and thawing. Lysis of a $1: 4$ suspension of 
leukocytes was carried out by rapid freezing and thawing of the preparation 3 times or more until microscopic examination indicated complete lysis of the cells. The lysate protein was recovered by high speed centrifugation, as described above.

Treatment with acetone. A 1:1 suspension of leukocytes in $0.08 \mathrm{M}$ phosphate buffer, $\mathrm{pH} 7.5$, was used in this procedure. The suspension was added rapidly to 10 vol of reagent grade acetone previously cooled to $-20^{\circ} \mathrm{C}$. After 1 minute of vigorous stirring, the suspension was filtered through Whatman 1 filter paper on a precooled Buchner funnel, and the residue was washed with an additional 10 vol of acetone. The residue was dried in a gentle stream of air, and the resultant powder was stored at $-20^{\circ} \mathrm{C}$. Five vol of the desired buffer was added to the powder, and the mixture was stirred mechanically for 30 minutes; the soluble protein was recovered by high speed centrifugation, as described above.

Lyophilization. One-ml portions of a $1: 4$ suspension of leukocytes were lyophilized to dryness (approximately 2 hours). The powder was extracted with 5 vol of water, and the soluble protein was collected as described above.

\section{Purification of formatc-activating enzyme from normal leukocytes}

Nine $\mathrm{ml}$ of lysate, containing $250 \mathrm{mg}$ of protein, was adjusted to $\mathrm{pH} 7.4$, and $2.8 \mathrm{ml}$ of $2 \%$ protamine sulfate was added. After the solution was stirred mechanically for 10 minutes, the precipitate was removed by centrifugation and discarded. Solid ammonium sulfate was added to the supernatant fluid until the concentration was increased to $35 \%$ saturation $(19.6 \mathrm{~g}$ per $100 \mathrm{ml})$, and the precipitate was discarded. The concentration of ammonium sulfate was then increased to $45 \%$ saturation by the addition of $6.3 \mathrm{~g}$ per $100 \mathrm{ml}$, and the resulting precipitate was collected by centrifugation and dissolved in $2 \mathrm{ml}$ of $0.05 \mathrm{M}$ Tris buffer, $\mathrm{pH} 7.5$. This procedure results in a five- to tenfold purification of the enzyme with a recovery of approximately $60 \%$.

\section{Purification of dihydrofolic reductase from leukemic leukocytes}

Two $\mathrm{g}$ of leukocyte acetone powder from a patient with leukemia was extracted for 1 hour with $20 \mathrm{ml}$ of $0.05 \mathrm{M}$ potassium phosphate buffer, $\mathrm{pH}$ 7.5. After centrifugation $(10,900 \times g$ for 15 minutes in the International refrigerated centrifuge, model PR-2), the supernatant fraction was collected and stirred mechanically for $15 \mathrm{~min}-$ utes with 0.3 vol of $2 \%$ protamine sulfate. The mixture was centrifuged, and the supernatant fluid $(17.7 \mathrm{ml})$ was treated with $6.5 \mathrm{~g}$ of ammonium sulfate; after centrifugation the precipitate ( 0 to $55 \%$ fraction) was discarded. To the supernatant fluid was added $5.4 \mathrm{~g}$ of ammonium sulfate to increase the concentration to $90 \%$. The resulting precipitate ( 55 to $90 \%$ fraction) was recovered by centrifugation, dissolved in $4.0 \mathrm{ml}$ of $0.05 \mathrm{M}$ phosphate buffer, $\mathrm{pH} 7.5$, and dialyzed overnight against $0.002 \mathrm{M}$ phosphate buffer, $\mathrm{pH}$ 7.5. Any precipitate that formed during dialysis was removed by centrifugation. The enzyme solution was treated with calcium phosphate gel as follows: $1 \mathrm{mg}$ of gel $(20 \mathrm{mg}$ per $\mathrm{ml})$ was added for each milligram of protein, and after adjusting the $\mathrm{pH}$ to 6.0 with $0.1 \mathrm{~N}$ acetic acid, the mixture was stirred for 10 minutes. After centrifugation, the gel was washed twice with $5-\mathrm{ml}$ portions of water, and the enzyme was desorbed with the two 2-ml portions of $0.1 \mathrm{M}$ phosphate buffer, $\mathrm{pH}$ 7.5. The enzyme preparation contained about $2.5 \mathrm{ml}$ of protein per $\mathrm{ml}$. At this stage, the enzyme has a specific activity (micromoles per hour per milligram protein) of approximately 0.3 to 0.4 ; this represents a purification of 15 to 20 times and a recovery of about $40 \%$ based upon the acetone powder extract.

The above procedure was employed for the routine preparation of dihydrofolic reductase. Further purification could be accomplished by chromatography of the enzyme on DEAE cellulose. In the experiment illustrated in Figure 1, a relatively large sample of reductase, purified by the above procedure $(112 \mathrm{mg}$ of protein, $\mathrm{SA}=$ 0.26 ), was made $10^{-3} \mathrm{M}$ with respect to phosphate, $\mathrm{pH}$ 7.2 , and then passed through a $2.2-\times 15-\mathrm{cm}$ column of DEAE cellulose. After adsorption of the protein, the column was eluted in a batchwise fashion with $10^{-3} \mathrm{M}$ phosphate solutions containing various concentrations of $\mathrm{KCl}$ as indicated on the diagram. Ten-ml fractions were collected and analyzed for protein (by absorbancy at $280 \mathrm{~m} \mu$ ) and for enzyme activity. Approximately onehalf of the total activity was recovered in tube 25 , and the $\mathrm{SA}$ was 0.90 in this fraction.

\section{RESULTS AND DISCUSSION}

Preparation of leukocyte lysates. Leukocytes were isolated from whole blood in about 2 hours by a procedure that consisted of the removal of platelets by centrifugation, removal of most of the erythrocytes by sedimentation in the presence of dextran (35), and selective lysis of the remaining erythrocytes in a hypotonic medium (36). A similar method has been devised by Fallon and associates (37). The yield of leukocytes was about $40 \%$ from normal blood and as high as 60 to $90 \%$ from leukemic blood. In normal blood there was some selective loss of lymphocytes during isolation so that the final suspension contained about $85 \%$ polymorphonuclear leukocytes.

The isolated leukocytes were essentially free from erythrocytes or platelets, and the cells were morphologically intact. When heparin, ACD, and EDTA were compared as anticoagulants for the collection of blood, no differences were found in the yield of leukocytes or in the enzyme activities.

For a given leukocyte preparation, comparable amounts of soluble protein are released by the 


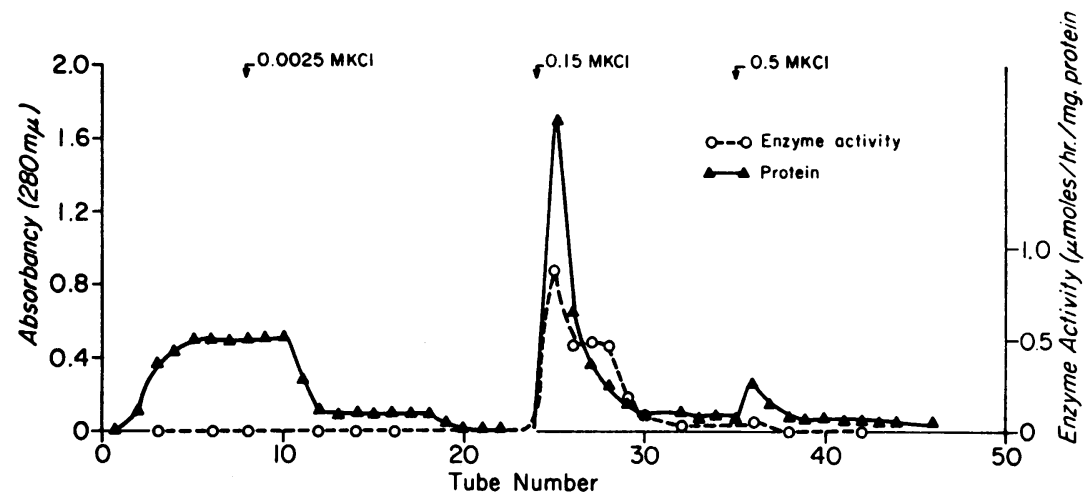

Fig. 1. Purification of Dihydrofolic REdUCtase by Chromatography on DEAE CELLuLOSE.

various lytic procedures described in the methods section. In a typical experiment in which samples of a normal leukocyte preparation were subjected to freezing and thawing, homogenization, and lyophilization, the amounts of soluble protein obtained per $10^{9}$ cells were 32,31 , and $37 \mathrm{mg}$, respectively.

The ranges of soluble protein encountered from different samples of a given cell type subjected to high-speed homogenization are compared in Table I. When the average value for 15 samples of normal cells, $46 \mathrm{mg}$ of protein per $10^{9}$ cells (range 30 to 67 ), is compared with average values from the various leukemic cell types, the amount of soluble protein is higher for chronic myelocytic leukemia, approximately the same for acute myeloblastic leukemia, and lower for chronic lymphocytic or acute lymphoblastic leukemia (child). In the latter two instances the lower level of soluble protein would be expected, since lymphocytes are small cells with a low cytoplasm: nucleus ratio.

TABLE I

Soluble protein from various cell types

\begin{tabular}{lrc}
\hline \hline \multicolumn{1}{c}{ Cell type } & No. of subjects & Soluble protein \\
\hline & & $m g / 10^{\circ}$ cells \\
Normal & 15 & $46(30-67)^{*}$ \\
CLL $\dagger$ & 5 & $20(15-25)$ \\
CML & 5 & $60(50-90)$ \\
AL & 10 & $35(24-45)$ \\
ALL (child) & 7 & $16(12-20)$
\end{tabular}

* Range of values.

$\uparrow \mathrm{CLL}=$ chronic lymphocytic leukemia; CML = chronic myelocytic leukemia; $\mathrm{AL}=$ acute leukemia; and ALL = acute lymphoblastic leukemia.
To ascertain whether the method of lysis had any effect upon the recovery of enzyme activity, three representative enzymes were assayed after homogenization, freezing and thawing, and lyophilization of samples of the same cell suspension of normal leukocytes. From the data in Table II, it is evident that the levels of formate-activating enzyme, $N^{5}, N^{10}$-methylene tetrahydrofolic dehydrogenase, and glucose-6-phosphate dehydrogenase are approximately the same, regardless of the lytic procedure employed.

Formate-activating enzyme. The formate-activating enzyme, which was detected earlier in normal leukocyte lysates (1), has been partially purified. Under optimal assay conditions, the extent of reaction was linear with time and with enzyme concentration, thus making it possible to define a unit of enzyme activity that may be used to compare the levels of this enzyme in lysates from various cell types.

The $\mathrm{pH}$ optimum of the leukocyte enzyme occurs at 7.4, and the reaction is carried out most

TABLE II

Effect of lysis on enzyme activity in normal leukocytes

\begin{tabular}{|c|c|c|c|}
\hline Method of lysis & $\begin{array}{c}\text { Formate- } \\
\text { activating } \\
\text { enzyme }\end{array}$ & $\begin{array}{c}N^{5}, N^{10}- \\
\text { methylene } \\
\text { tetra- } \\
\text { hydrofolic } \\
\text { dehydro- } \\
\text { genase }\end{array}$ & $\begin{array}{c}\text { Glucose- } \\
\text { 6-phosphate } \\
\text { dehydrogenase }\end{array}$ \\
\hline & \multicolumn{3}{|c|}{$\begin{array}{c}\mu m o l e s / h r / 10^{9} \\
\text { cells }\end{array}$} \\
\hline Homogenization & 14.3 & 5.3 & 525 \\
\hline $\begin{array}{l}\text { Freezing and } \\
\text { thawing }\end{array}$ & 18.4 & 5.3 & 475 \\
\hline Lyophilization & 15.0 & 3.6 & 520 \\
\hline
\end{tabular}


TABLE III

Component study for leukocyte formate-activating enzyme*

\begin{tabular}{|c|c|}
\hline Component omitted & $N^{10}-$ formyl tetrahydrofolate \\
\hline & $m \mu m o l e s$ \\
\hline None & 20.0 \\
\hline $\mathrm{NH}_{4}^{+}$ & 9.0 \\
\hline $\mathrm{Mg}^{++}$ & 2.0 \\
\hline Formate & 2.0 \\
\hline ATP & 0.7 \\
\hline Tetrahydrofolate & 0.4 \\
\hline Enzyme & 0 \\
\hline
\end{tabular}

* The assay system is described in the methods section; results are expressed as millimicromoles of product formed in 20 minutes, with $0.2 \mathrm{mg}$ of protein from a normal cell lysate used as the enzyme source.

suitably in Tris buffer; phosphate buffer is markedly inhibitory. A component study for Reaction 1 ,

formate $+\mathrm{ATP}+$ tetrahydrofolate $\rightleftharpoons N^{10_{-}}$ formyl tetrahydrofolate $+\mathrm{ADP}+\mathrm{P}_{\mathbf{i}}$

catalyzed by the leukocyte enzyme, is presented in Table III. In addition to the substrates (ATP, tetrahydrofolate, and formate), the enzyme requires $\mathrm{Mg}^{++}$(or $\mathrm{Mn}^{++}$) and $\mathrm{K}^{+}$(or $\mathrm{NH}_{4}{ }^{+}$). Michaelis constants have been determined for the three substrates in Reaction 1: formate, $K_{m}=2 \times$ $10^{-3} \mathrm{M}$; ATP, $\mathrm{K}_{\mathrm{m}}=4 \times 10^{-5} \mathrm{M}$; and tetrahydrofolate, $\mathrm{K}_{\mathrm{m}}=8 \times 10^{-4} \mathrm{M}$. The $\mathrm{pH}$ optimum, metal ion requirements, and Michaelis constants are the same for the formate-activating enzyme isolated from both normal and leukemic leukocytes. Many of the common chemotherapeutic agents (e.g., aminopterin, amethopterin, 6-mercaptopurine, busulfan, chlorambucil, and nitrogen mustard), which might be expected to be present in leukocytes from treated leukemic patients, do not inhibit the isolated formate-activating enzyme when these agents are tested at a level of $10^{-5} \mathrm{M}$.

Levels of formate-activating enzyme in normal and leukemic leukocytes. Table IV presents a summary of the levels of formate-activating enzyme in normal leukocytes and in cells from various leukemia patients. Such enzyme levels may be expressed as activity: $a$ ) per milligram of soluble protein, or $b$ ) per $10^{9}$ cells. The level of formate-activating enzyme in the small cells of chronic lymphocytic leukemia is only $50 \%$ of the normal level when expressed on the basis of $10^{9}$ cells, but when compared in terms of soluble protein, the values are equivalent. On the other hand, the enzyme level in cells of acute leukemia (adult) is elevated with respect to the normal level on either a cellular or protein basis. Because of the difference in the amount of soluble protein released from the various cell types (Table I) and the greater accuracy of the protein determination as compared with leukocyte counts, it appeared preferable in this investigation to express all subsequent data as activity per milligram of protein.

Level of other enzymes involved in 1-carbon metabolism and carbohydrate metabolism. The levels of two other enzymes that utilize tetrahydrofolate as a coenzyme, namely, $N^{5}, N^{10}$-methylene tetrahydrofolic dehydrogenase and serine hydroxymethylase, are summarized in Table V. The amount of the former enzyme is essentially the same in normal cells and cells of the chronic leukemias, whereas the level in the acute leukemic cells of the adult or child is twice normal. Serine hydroxymethylase activity is about the same in normal and chronic myelocytic leukemic cells, about 1.5 to 2 times higher than normal in the acute leukemias, and 10 times higher in cells of chronic lymphocytic leukemia. The greatly elevated level of the enzyme in chronic lymphocytic leukemic cells may provide an explanation for Winzler's earlier observation (11) that the rate of incorporation of $\mathrm{C}^{14}$-formate into protein, presumably into the serine residues, is higher in these cells than in normal cells.

Cyclohydrolase has been detected in normal and chronic lymphocytic leukemic leukocytes at a level of approximately $0.3 \mu$ mole per hour per $\mathrm{mg}$ of protein, but no detailed investigation was made of the comparative levels of this enzyme in various cell types. On the other hand, $N^{10}$-formyl tetrahydrofolic deacylase is either nonexistent in nor-

TABLE IV

Levels of formate-activating enzyme in leukocytes

\begin{tabular}{|c|c|c|c|}
\hline \multirow[t]{2}{*}{ Cell type } & \multirow[t]{2}{*}{ No. of subjects } & \multicolumn{2}{|c|}{$\begin{array}{l}N^{10_{-} \text {formyl tetrahydrofolate }} \\
\text { formed }\end{array}$} \\
\hline & & $\underset{\text { protein }}{\mu m o l e s / h r} / m g$ & $\begin{array}{l}\text { 4moles } / \mathrm{hr} / \\
10^{9} \mathrm{cells}\end{array}$ \\
\hline Normal & 14 & $0.38 \pm 0.03^{*}$ & $15.9 \pm 1.4$ \\
\hline CLLt & 8 & $0.41 \pm 0.03$ & $7.3 \pm 0.9$ \\
\hline CML & 12 & $0.62 \pm 0.08$ & $37.4 \pm 6.5$ \\
\hline AL & 17 & $0.96 \pm 0.08$ & $35.1 \pm 4.8$ \\
\hline ALL (child) & 10 & $0.76 \pm 0.06$ & $19.7 \pm 3.4$ \\
\hline
\end{tabular}

$*$ Mean $\pm \mathrm{SE}$

† Abbreviations as in Table I. 
TABLE $\mathrm{V}$

Levels of $N^{5}, N^{10}$-methylene tetrahydrofolic dehydrogenase, serine hydroxymethylase, glucose-6-phosphate dehydrogenase, and lactic dehydrogenase in normal and leukemic leukocytes

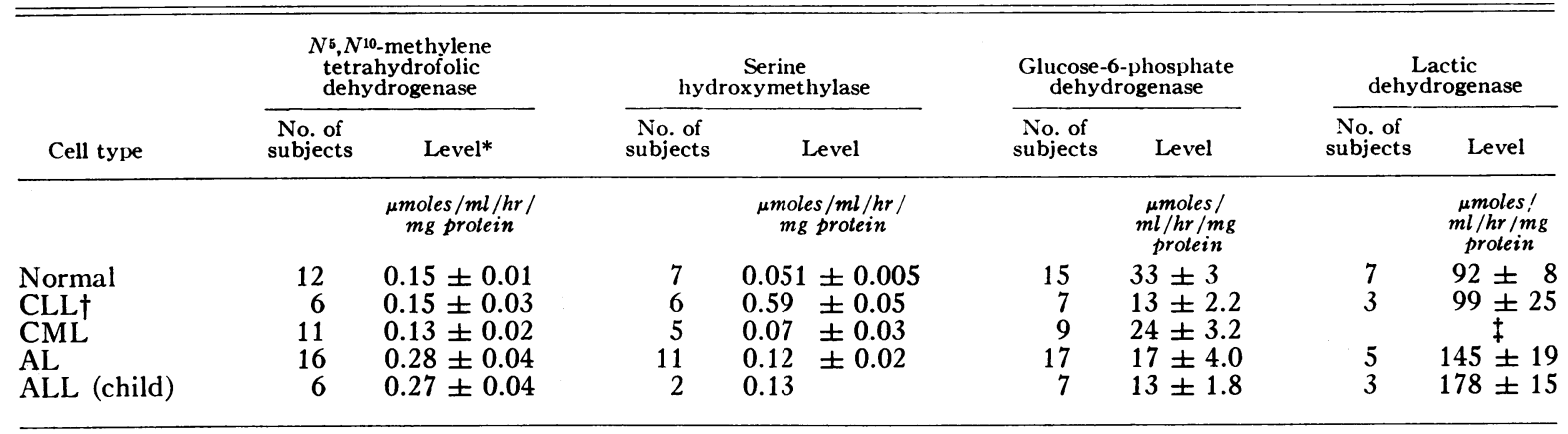

* Mean \pm SE.

† Abbreviations as in Table I.

‡ Data not available.

mal and leukemic leukocytes or else the activity is too low to be detected by the present assay method.

For comparative purposes, a study was made of two representative enzymes of carbohydrate metabolism, namely, glucose-6-phosphate dehydrogenase and lactic dehydrogenase. The results are given also in Table V. As compared with normal cells, the level of glucose-6-phosphate dehydrogenase is decreased by about $50 \%$ in acute leukemia and chronic lymphocytic leukemia, and to a lesser extent in chronic myelocytic leukemia. Lactic dehydrogenase activity is elevated above normal in acute leukemia, but not in chronic lymphocytic leukemia. The lower levels of glucose-6-phosphate dehydrogenase in leukocytes from chronic myelocytic and chronic lymphocytic leukemia patients are in agreement with the observations of Beck (38).

The above results characterize the leukocytes from chronic myelocytic leukemia and acute leukemia as cells containing higher levels of tetrahydrofolate-dependent enzyme systems when compared to normal leukocytes. This is consistent with the fact that these cells, even in the peripheral circulation, are capable of synthesizing DNA (39), and tetrahydrofolate-dependent enzymes are involved, among other things, in the formation of the purine ring and the methyl group of the pyrimidine, thymine. Similarly, other enzymes involved in nucleic acid synthesis have been shown to be elevated in leukemic leukocytes when compared to normal leukocytes, e.g., several enzymes in the pyrimidine biosynthesis pathway (40), thymidylate synthetase (41), and DNA polymerase (42). The question might be raised as to whether such quantitative enzymatic differences observed between leukemic and normal leukocytes are inherent characteristics of the leukemic cell or whether they are also found in normal cells of comparable type and maturity. The finding of increased activity of tetrahydrofolate-dependent enzymes in lysates prepared from normal bone marrow aspirations ${ }^{18}$ suggests that these alterations may not be specific for leukemia. This problem is difficult to resolve, however, until techniques become available for preparing immature normal cells of a uniform type (e.g., myeloblasts) for comparative purposes.

Dihydrofolic reductase from leukemic leukocytes. Although the levels of the above tetrahydrofolate-dependent enzymes are about 2 times higher in acute leukemic cells as compared with normal cells, they are essentially insensitive to the folic acid antagonists. On the other hand, dihydrofolic reductase, the enzyme responsible for the conversion of folate and dihydrofolate to tetrahydrofolate, has been shown to be extremely sensitive to the antagonists, thereby provicling an explanation for the effectiveness of these agents in the chemotherapy of leukemia. Additional interest in dihydrofolic reductase has been stimulated by the demonstration (43) that the enzyme also participates in the reductive methylation of deoxyuridylate to yield thymidylate (41). 
The leukocyte dihydrofolic reductase has been purified approximately 20 times with a recovery of about $37 \%$. When additional purification is carried out by means of chromatography on DEAE cellulose, as in Figure 1, material with SA of 0.9 may be obtained. The purified enzyme is colorless, stable to dialysis, and may be stored at $-20^{\circ} \mathrm{C}$ for at least 6 months.

The $\mathrm{pH}$ optimum for the reduction of dihydrofolate occurs at 8.3 to 8.5 , and there is a smaller optimum near 5. In contrast, the $\mathrm{pH}$ optimum for the dihydrofolic reductase from chicken liver occurs at $\mathrm{pH} 4.8$, with a smaller peak at 7.5 (44). A study of substrate and cofactor requirements for the leukocyte reductase revealed that TPNH was considerably more effective than $\mathrm{DPNH}$ at $\mathrm{pH} 8.5$ in the reduction of dihydrofolate ( 0.90 versus $0.08 \mu$ moles per hour per mg protein). The reduction of folate could not be demonstrated at $\mathrm{pH} 8.3$ in the presence of either TPNH or DPNH, but a small activity $(0.03 \mu$ moles per hour per $\mathrm{mg}$ protein) was observed with TPNH at $\mathrm{pH}$ 5.5. Stimulation of the leukocyte enzyme by $\mathrm{K}^{+}$or $\mathrm{NH}_{4}{ }^{+}$has been observed, as in the case of dihydrofolic reductases from other tissues (45). As reported previously, the Michaelis constants for $\mathrm{TPNH}$ and dihydrofolate with the leukocyte reductase are $3 \times 10^{-6} \mathrm{M}$ and $1 \times 10^{-6} \mathrm{M}$, respectively (14). It was found that dihydrofolic reductases, purified from cells of patients with either acute or chronic myelocytic leukemia, had the same $\mathrm{pH}$ optima, Michaelis constants, and requirement for cofactors. Most significantly, the leukocyte reductase is inhibited appreciably by the folic acid antagonists, aminopterin, amethopterin, and dichloroamethopterin at $10^{-8} \mathrm{M}$ [Table II (14) ; Figure 1 (46)].

Levels of dihydrofolic reductase in normal subjects and untreated leukemia patients. In lysates

TABLE VI

Activity of dihydrofolic reductase in leukocytes

\begin{tabular}{|c|c|c|}
\hline Diagnosis & No. of subjects & Activity \\
\hline $\begin{array}{l}\text { Normal } \\
\text { CLL* } \\
\text { CML } \\
\text { AL }\end{array}$ & $\begin{array}{r}15 \\
8 \\
10 \\
22\end{array}$ & $\begin{array}{c}\mu m o l e s / h r / m g \text { protein } \\
\text { about } 0.001 \\
0.002 \pm 0.001 \dagger \\
0.042 \pm 0.008 \\
0.034 \pm 0.004\end{array}$ \\
\hline
\end{tabular}

* Abbreviations as in Table I.

$\dagger$ Mean $\pm \mathrm{SE}$. of chronic myelocytic or acute leukemia cells, dihydrofolic reductase is detected readily with the "indirect" assay; as shown in Table VI, the level of this enzyme is approximately the same in both cell types (about $0.04 \mu$ mole per hour per mg protein). All of the leukemia patients were either untreated or were in relapse after treatment with chemotherapeutic agents other than folic acid antagonists. Further studies on the increased level of leukocyte dihydrofolic reductase, after treatment of leukemic patients with amethopterin, have been described elsewhere $(17,18)$.

We have reported previously (14) that dihydrofolic reductase could not be detected in normal and chronic lymphocytic leukemic leukocytes when these assays were performed with amounts of lysate protein up to $1.5 \mathrm{mg}$. When higher concentrations of lysate protein were used ( 5 to 10 $\mathrm{mg}$ per $\mathrm{ml}$ ), however, a small, but significant, enzyme activity could be demonstrated in both the normal and chronic lymphocytic leukemic cells (Table VI). Since these levels are at the lower limit of accuracy of the assay, dihydrofolic reductase was measured in a partially purified fraction from pooled samples of each cell type. For example, in the 55 to $90 \%$ ammonium sulfate fraction from pooled, chronic lymphocytic leukemia lysates, a value was found that corresponded to $0.02 \mu$ mole per hour per $\mathrm{mg}$ of protein (average of four separate experiments) for the reductase level in the original lysate. Thus the level in chronic myelocytic and acute leukemia cells is about 30 to 40 times higher than in normal cells.

\section{SUM MARY}

1) Leukocytes have been isolated from blood by a procedure consisting of removal of platelets by centrifugation, removal of the majority of erythrocytes by sedimentation in the presence of dextran, and selective lysis of the remaining erythrocytes in a hypotonic medium. Lysis of the isolated leukocytes was accomplished by high-speed homogenization, repeated freezing and thawing, or treatment with acetone at low temperature.

2) Levels of the following enzymes have been measured in normal and leukemic leukocytes: formate-activating enzyme, $N^{5}, N^{10}$-methylene tetrahydrofolic dehydrogenase, serine hydroxymethylase, cyclohydrolase, dihydrofolic reductase, glu- 
cose-6-phosphate dehydrogenase, and lactic dehydrogenase. The level of dihydrofolic reductase is elevated about 30 times in chronic myelocytic and acute leukemic cells as compared with normal and chronic lymphocytic leukemic cells.

3) Formate-activating enzyme and dihydrofolic reductase have been partially purified from leukocytes. The following properties of these enzymes were determined: $\mathrm{pH}$ optimum, substrate and co-factor specificity, metal ion requirements, Michaelis constants, and sensitivity to inhibitors. Dihydrofolic reductase is inhibited by aminopterin and amethopterin at $10^{-8} \mathrm{M}$.

\section{ACKNOWLEDGMENTS}

We are indebted to Drs. J. R. Czajkowski, D. H. Coleman, Q. B. DeMarsh, D. M. Donohue, C. A. Finch, J. R. Hartmann, and A. R. Stevens for providing us with blood specimens.

\section{REFERENCES}

1. Bertino, J. R., A. Alenty, B. W. Gabrio, and F. M. Huennekens. Folic acid coenzymes and one-carbon metabolism in leukocytes. Clin. Res. 1960, 8, 206.

2. Bertino, J. R., B. W. Gabrio, and F. M. Huennekens. Increased activity of leukocyte dihydrofolic reductase in amethopterin-treated patients. Clin. Res. 1961, 9, 103.

3. Valentine, W. N. The metabolism of the leukemic leukocyte. Amer. J. Med. 1960, 28, 699.

4. Aisenberg, A. C. The Glycolysis and Respiration of Tumors. New York, Academic Press, 1961, pp. 20-23.

5. Valentine, W. N., J. H. Follette, D. H. Solomon, and J. Reynolds. Biochemical and enzymatic characteristics of normal and leukemic leukocytes (with particular reference to leukocyte alkaline phosphatase) in The Leukemias: Etiology, Pathophysiology, and Treatment, J. W. Rebuck, F. H. Bethell, and R. W. Monto, Eds. New York, Academic Press, 1957, p. 457.

6. Beck, W. S., and W. N. Valentine. The carbohydrate metabolism of leukocytes: a review. Cancer Res. 1953, 13, 309.

7. Huennekens, F. M., and M. J. Osborn. Folic acid coenzymes and one-carbon metabolism. Advanc. Enzymol. 1959, 21, 369.

8. Rabinowitz, J. C. Folic acid in The Enzymes, P. D. Boyer, H. A. Lardy, and K. Myrback, Eds. New York, Academic Press, 1960, vol. 2, p. 185.

9. O'Brien, J. S. The role of the folate coenzymes in cellular division. A review. Cancer Res. 1962, 22, 267.

10. Ellison, R. R., and D. J. Hutchison. Metabolism of folic acid and citrovorum factor in leukemic cells in The Leukemias: Etiology, Pathophysiology, and Treatment, J. W. Rebuck, F. H. Bethell, and R. W. Monto, Eds. New York, Academic Press, 1957, p. 467.

11. Winzler, R. J. Anti-cancer agents and nucleic acid metabolism of isolated human leukocytes in The Leukemias : Etiology, Pathophysiology, and Treatment, J. W. Rebuck, F. H. Bethell, and R. W. Monto, Eds. New York, Academic Press, 1957, p. 567 .

12. Wells, W. In vitro incorporation of formate into nucleic acid derivatives of normal and leukemic human leukocytes. Ph.D. thesis, University of Illinois, 1959.

13. Winzler, R. J. Differences in nucleic acid metabolism between normal and leukemic human leukocytes. Ann. N. Y. Acad. Sci. 1958, 75, 37.

14. Bertino, J. R., B. W. Gabrio, and F. M. Huennekens. Dihydrofolic reductase in human leukemic leukocytes. Biochem. biophys. Res. Commun. 1960, 3, 461.

15. Wilmanns, W. Die tetrahydrofolsäure-abhangige Activierung von Einkohlenstoffeinheiten in normalen und pathologischen weissen Blutzellen. Klin. Wschr. 1961, 39, 884.

16. Wilmanns, W. Bestimmung, Eigenschaften und Bedeutung der Dihydrofolsäure-Reduktase in den weissen Blutzellen bei Leukämien. Klin. Wschr. 1962, 40, 533.

17. Bertino, J. R., D. M. Donohue, B. W. Gabrio, R. Silber, A. Alenty, M. Meyer, and F. M. Huennekens. Increased level of dihydrofolic reductase in leukocytes of patients treated with amethopterin. Nature (Lond.) 1962, 193, 140.

18. Bertino, J. R., D. M. Donohue, B. Simmons, B. W. Gabrio, R. Silber, and F. M. Huennekens. The "induction" of dihydrofolic reductase activity in leukocytes and erythrocytes of patients treated with amethopterin. J. clin. Invest. 1963, 42, 466.

19. Futterman, S. Enzymatic reduction of folic acid and dihydrofolic acid to tetrahydrofolic acid. J. biol. Chem. 1957, 228, 1031.

20. Hatefi, Y., P. T. Talbert, M. J. Osborn, and F. M. Huennekens. Tetrahydrofolic acid. Biochem. Preparations 1960, 7, 89.

21. May, M., T. J. Bardos, F. L. Barger, M. Lansford, J. M. Ravel, G. L. Sutherland, and W. Shive. Synthetic and degradative investigations of the structure of folinic acid-SF. J. Amer. chem. Soc. 1951, 73, 3067.

22. Rabinowitz, J. C., and W. E. Pricer, Jr. Formiminotetrahydrofolic acid and methenyltetrahydrofolic acid as intermediates in the formation of $\mathrm{N}^{10}$ formyltetrahydrofolic acid. J. Amer. chem. Soc. 1956, 78, 5702.

23. Whiteley, H. R., M. J. Osborn, and F. M. Huennekens. Purification and properties of the formateactivating enzyme from Micrococcus aerogenes. J. biol. Chem. 1959, 234, 1538. 
24. Ozols, J. G. Chemical synthesis of model compounds related to folic acid coenzymes. $\mathrm{Ph} . \mathrm{D}$. thesis, University of Washington, 1962.

25. Layne, E. Spectrophotometric and turbidometric methods for measuring proteins. III. Biuret method in Methods in Enzymology, S. P. Colowick and N. O. Kaplan, Eds. New York, Academic Press, 1957, 3, 450.

26. Whiteley, H. R., and F. M. Huennekens. Mechanism of the reaction catalyzed by the formateactivating enzyme from Micrococcus aerogenes. J. biol. Chem. 1962, 237, 1290.

27. Osborn, M. J., and F. M. Huennekens. Participation of anhydroleucovorin in the hydroxymethyl tetrahydrofolic dehydrogenase system. Biochim. biophys. Acta (Amst.) 1957, 26, 646.

28. Hatefi, Y., M. J. Osborn, L. D. Kay, and F. M. Huennekens. Hydroxymethyl tetrahydrofolic dehydrogenase. J. biol. Chem. 1957, 227, 637.

29. Osborn, M. J., Y. Hatefi, L. D. Kay, and F. M. Huennekens. Evidence for the enzymic deacylation of $\mathrm{N}^{10}$-formyl tetrahydrofolic acid. Biochim. biophys. Acta (Amst.) 1957, 26, 208.

30. Whiteley, H. R. The distribution of the formateactivating enzyme and other enzymes involving tetrahydrofolic acid in animal tissues. Comp. Biochem. Physiol. 1960, 1, 227.

31. Scrimgeour, K. G., and F. M. Huennekens. Folic acid-dependent enzymes involved in one-carbon metabolism in Handbuch der Physiologisch und Pathologisch-Chemischen Analyse. Heidelberg, Springer, vol. 6, in press.

32. Scrimgeour, K. G., and F. M. Huennekens. Serine hydroxymethylase in Methods in Enzymology, S. P. Colowick and N. O. Kaplan, Eds. New York, Academic Press 1962, vol. 5, p. 838.

33. Kornberg, A., and B. L. Horecker. Glucose-6phosphate dehydrogenase in Methods in Enzymology, S. P. Colowick and N. O. Kaplan, Eds. New York, Academic Press, 1955, vol. 1, p. 323.

34. Kubowitz, F., and P. Ott. Isolierung and Kristallisation eines Gärungsfermentes aus Tumoren. Biochem. Z. 1943, 314, 94.
35. Skoog, W. A., and W. S. Beck. Studies on the fibrinogen, dextran and phytohemagglutinin methods of isolating leukocytes. Blood 1956, 11, 436.

36. Walford, R. L., E. T. Peterson, and P. Doyle. Leukocyte antibodies in human sera and in immune rabbit sera. Blood 1957, 12, 953.

37. Fallon, H. J., E. Frei, III, J. D. Davidson, J. S. Trier, and D. Burke. Leukocyte preparations from human blood: evaluation of their morphologic and metabolic state. J. Lab. clin. Med. 1962, 59, 779.

38. Beck, W. S. The control of leukocyte glycolysis. J. biol. Chem. 1958, 232, 251.

39. Craddock, C. G., and G. S. Nakai. Leukemic cell proliferation as determined by in vitro deoxyribonucleic acid synthesis. J. clin. Invest. 1962, 41, 360.

40. Smith, L. H., Jr., F. A. Baker, and M. Sullivan. Pyrimidine metabolism in man. II. Studies of leukemic cells. Blood 1960, 15, 360 .

41. Silber, R., B. W. Gabrio, and F. M. Huennekens. Studies on normal and leukemic leukocytes. VI. Thymidylate synthetase and deoxycytidylate deaminase. J. clin. Invest. 1963, 42, 1913.

42. Bianchi, P. A. Thymidine phosphorylation and deoxyribonucleic acid synthesis in human leukaemic cells. Biochim biophys. Acta (Amst.) 1962, 55, 547.

43. Wahba, A. J., and M. Friedkin. The enzymatic synthesis of thymidylate. I. Early steps in the purification of thymidylate synthetase of Escherichia coli. J. biol. Chem. 1962, 237, 3794.

44. Mathews, C. K. Enzymatic interconversions of folic acid, dihydrofolic acid, and tetrahydrofolic acid. Ph.D. thesis, University of Washington, 1962.

45. Bertino, J. R. Activation of tetrahydrofolate dehydrogenase by certain cations. Biochim. biophys. Acta (Amst.) 1962, 58, 377.

46. Silber, R., F. M. Huennekens, and B. W. Gabrio. Studies on the interaction of tritium-labeled aminopterin with dihydrofolic reductase. Arch. Biochem. 1962, 100, 525. 